Provided for non-commercial research and education use. Not for reproduction, distribution or commercial use.

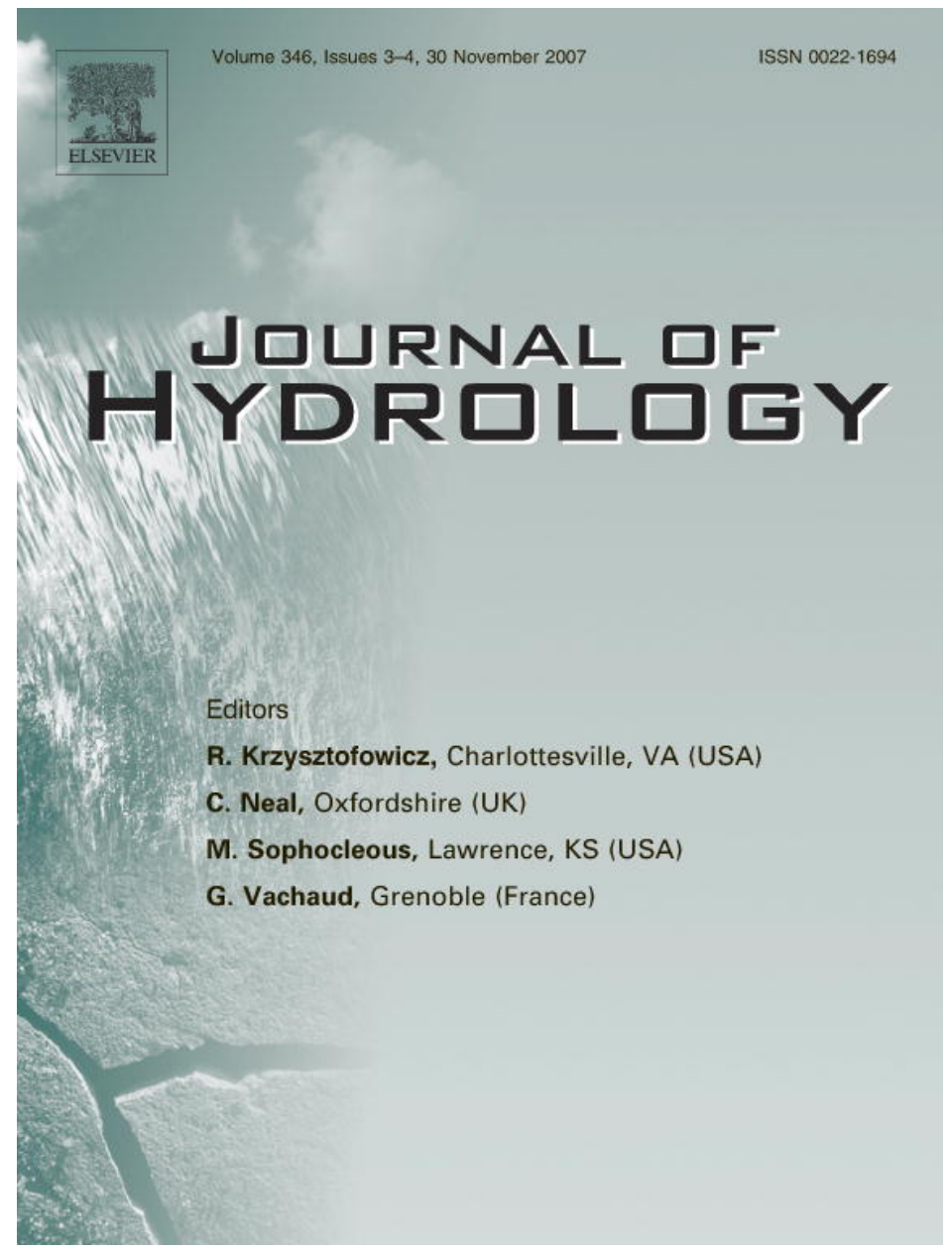

This article was published in an Elsevier journal. The attached copy

is furnished to the author for non-commercial research and education use, including for instruction at the author's institution, sharing with colleagues and providing to institution administration.

Other uses, including reproduction and distribution, or selling or licensing copies, or posting to personal, institutional or third party websites are prohibited.

In most cases authors are permitted to post their version of the article (e.g. in Word or Tex form) to their personal website or institutional repository. Authors requiring further information regarding Elsevier's archiving and manuscript policies are encouraged to visit: 


\title{
Investigating the spatial and temporal boundaries of Hortonian and Hewlettian runoff in Northern Mexico
}

\author{
Luc Descroix $^{a, *}$, David Viramontes ${ }^{a, 1}$, Juan Estrada ${ }^{b}$, \\ José-Luis Gonzalez Barrios ${ }^{b}$, Jean Asseline ${ }^{c}$
}

\author{
a IRD LTHE, Laboratoire d'étude des Transferts en Hydrologie et Environnement, BP 53, 38041 Grenoble cedex 9 , France \\ ${ }^{b}$ Cenid Raspa INIFAP, Ap 225-3 Gomez Palacio ZI, 35000 DGO, Mexico \\ c IRD BP 64501, 34394 Montpellier cedex 5, France
}

Received 7 October 2006; received in revised form 12 July 2007; accepted 5 September 2007

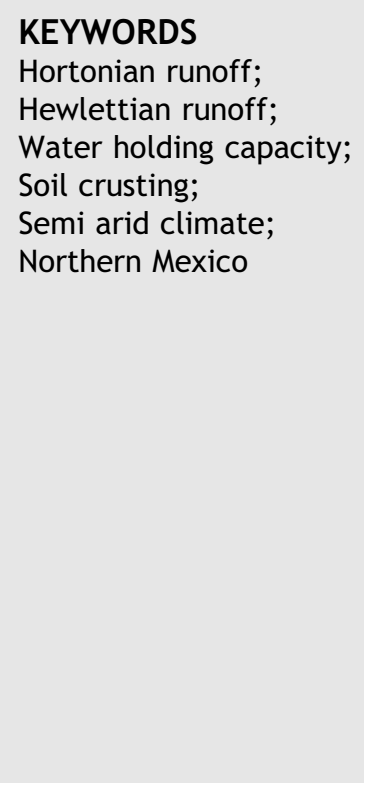

Summary Soil surface features strongly determine whether rain water will infiltrate or runoff. This results in a segregation between several kinds of hydrological functioning of hillslopes and catchments. Using a deterministic model, it is attempted to define the spatial and temporal boundaries of Hortonian (infiltration excess runoff) and Hewlettian (saturation excess overland flow) hydrological behaviour. The model allows to calculate the role of the antecedent precipitation index and the soil water holding capacity in the runoff yield. These factors depend on soil hydrodynamic properties.

In Northern Mexico, data collected in four experimental networks are used: one in the sub-humid Western Sierra Madre, one in its semi-arid foothill, one in the centre of the endoreic Bolson de Mapimi (the southern part of Chihuahuan desert) and the last one on the southern edge of the latter, in a limestone range. There is a regional distribution of these parameters because of rainfall distribution and overall because of the whole ecological context. The value of $\alpha$ parameter (which determines the depletion time of soil water content) and the proportion of bare soils are the most important explaining factors of geographical segregation between Hortonian and Hewlettian contexts.

This study determines that the Western Sierra Madre, with its temperate climate, is mostly characterized by a Hewlettian hydrology, despite an increase in Hortonian behaviour due particularly to land degradation. Inversely, as it is well known, Hortonian runoff dominates completely the semi-arid and arid areas; however in certain circumstances, saturation excess overland flow can appear due to landscape or local roughness, and local

\footnotetext{
${ }^{*}$ Corresponding author. Present address: IRD, BP 11 416, Niamey, Niger.

E-mail addresses: descroix@ird.ne (L. Descroix), david.viramontes@wanadoo.fr (D. Viramontes), estrada.juan@inifap.gob.mx (J. Estrada), gonzalez.barrios@inifap.gob.mx (J.-L. Gonzalez Barrios), asseline@mpl.ird.fr (J. Asseline).

1 CNRS UMR 8591 Laboratoire de Géographie Physique, 1 Place Aristide Briand, F92195 Meudon Cedex, France.
} 
or temporal possibility to infiltrate a great proportion of rainwater, i.e. during low intensity-large duration events (hurricanes crossing the mountains, winter rainy events linked to El Niño Southern Oscillation configuration).

(c) 2007 Elsevier B.V. All rights reserved.

\section{Introduction}

Humid temperate areas and tropical rain forest are traditionally regarded as environments with low runoff and low erosion potential. The runoff generation is dominated there by subsurface stormflow (SSSF) and by saturation excess overland flow (SOF) (Cappus, 1960; Hewlett, 1961; Dunne and Black, 1970). In both environments, soils are characterized by a good structure and well developed Ahorizons. As a result, rainfall intensities are usually lower than the soil's infiltration capacities (Bonell and Gilmour, 1978). This kind of behaviour inspired the Hewlett "variable source area"' concept (Hewlett, 1961). However, Bonell and Gilmour (1978) noticed that in Australia's tropical rain forest, this concept does not always apply because of the characteristics of rainfall intensity. This has also been described in Southern France (Cevennes mountains), where strong intensity rainfall can exceed the high infiltration capacity of soils (Cosandey, 1994) and where rapid flow can occur in accordance with the "saturation contributing areas" (Dunne and Black, 1970). In Australia again, but in eucalyptus forests, it has been observed that excess infiltration runoff can appear in certain conditions after harvesting operations (Croke et al., 1999). Otherwise, it is generally accepted that the slope encourages surface runoff (Tricker, 1981); however it has been demonstrated in the Western Sierra Madre that soil surface features have much more influence on runoff yield than slope (Descroix et al., 2002b): steep slopes are protected by stones that increase infiltration.

In arid and semi-arid areas, as well as in degraded areas of the Mediterranean mountains, the excess infiltration runoff is widespread, as it is in North America (Goodrich et al., 1997), South America (Braud et al., 2001), and in Africa (Chevalier, 1983; Albergel, 1987; Casenave and Valentin, 1989; Ribolzi et al., 2007). In Europe, semi-arid areas have Hortonian runoff under climatic aridity (i.e. in Spain, Bergkamp, 1998), as well as under edaphic aridity (Esteves et al., 2005). It has been shown that the spatial variability of $K_{s}$, the saturated soil hydraulic conductivity, has a dominant role in the generation of Hortonian overland flow, for example in Central Italy (Corradini et al., 1998), where re-infiltration (run-on) is also favoured by this spatial variability. A similar observation was made in the Western Sierra Madre (Descroix et al., 2002b).

In the Sahel (West Africa), the areas covered by crusted soils increased significantly in the last decades because of changes in land use: the bush is replaced by cultivated or grazing land; Demographic pressure leads to overgrazing and soil overexploitation, resulting in a severe increase in soil losses (Karambiri et al., 2003) and in a paradoxal observation: despite a decrease of rainfall in $20-30 \%$, during the years of 1968-1995 as compared to the period of 1950 1967, the runoff coefficient in experimental catchments in the Sahelian region (an area with annual rainfall ranging from 300 to $700 \mathrm{~mm}$ ) rose dramatically (up to 100\%) between the 1960s and the 1980s (Albergel, 1987). This same observation was also made at the basin scale with an increase in discharges, in the Nakambé river in Burkina Faso (Mahé et al., 2002), and in the mid region of the Niger River (Amani and Nguetora, 2002). Runoff is increasing because the soil water holding capacity is reduced by changes in land use (Mahé et al., 2002). In a small basin in northern Burkina, it has been shown that stormflows are composed primarily of "new water" with minimal "old water" proving the predominance of instantaneous runoff (Ribolzi et al., 2007). This increase in runoff does not apply southward, neither in Sudanian (700-1300 mm of annual rainfall) nor in Guinean areas (where annual rainfall exceeds $1300 \mathrm{~mm}$ ). There, runoff is reduced significantly more than the observed diminution of rainfall (Mahé et al., 2002); for example, the Niger River mean annual discharge in Niamey (Niger) decreased by 55\% from 1968 to 1995 when compared with 1950-1967, although rainfall only decreased by $25-30 \%$ (Descroix et al., 2005b).

Nevertheless, the "Hortonian" characteristics of soils and slopes, often observed at the small catchment or the plot scale, result in the quasi absence of base flow. This has been observed in semi-arid northern Mexico for catchment as large as tens of thousands $\mathrm{km}^{2}$, and for approximately $500 \mathrm{~km}^{2}$ in the Western Sierra Madre. Latron and Gallart (2007) determined that in a "Hewlettian" context, there is a strong relationship between the base flow and the extension of saturated areas at the basin scale. Regardless of the land area, two main space variables highly impact the water yield: the land cover and the heterogeneity of the landscape. In semi-arid China, shrubland was seen as more prone to buffer runoff than grassland, woodland, pastureland and cropland (Wei et al., 2007). In Australia's semiarid rangelands, patches of bare soils were determined to be the main runoff controlling factor (Bartley et al., 2006); this paper highlights the impact of the bare soil's disposition pattern on runoff and soil losses. It explains the benefit of using hydrological models which take into account the connectivity (as the CRUM, Connectivity of Runoff Model) for semi-arid areas (Reaney et al., 2006); this also applies in more humid regions, where the landscape fragmentation buffers the land use change (from forest to cropland) from producing Hortonian runoff areas (Ziegler et al., 2007).

However, between these two kinds of environments (temperate and tropical humid regions on the one hand, and arid or semi-arid on the other), what is the hydrological behaviour of slopes and catchments?

In some arid or semi-arid areas (with the presence of large trees in certain places) with crusted soils, characterized by low clay and organic matter contents and low structural stability, weak infiltration and soil water holding capacity lead to the dominance of Hortonian hydrological behaviour. It is defined by runoff due to rainfall intensity 
exceeding the soil infiltration capacity (Horton, 1933 and Horton, 1940); in the "Hortonian" runoff process, the soil is filled from the top, and this topsoil is characterized by a low hydraulic conductivity; therefore only rainfall of long duration and low intensity can saturate the soil and trigger another kind of runoff.

In tree-savannas and clear forest in the sub-humid regions, the soils have higher organic matter content and sometimes higher clay content, and thus a better structural stability and hydraulic conductivity, with few instance of crusted topsoil. They are characterized by "Cappus-type" (Cappus, 1960) or "Hewlett-type"' (Hewlett, 1961, 1972) behaviour, where soil water holding capacity plays an important role in water balance and in the runoff yield, due to the presence of temporary water storage areas, perched water tables, under flows, preferential infiltration paths, etc. In this hydrological pattern, the soil is saturated from its bottom, acting like a reservoir filled by its deeper layer. Runoff only appears when the soil is saturated, avoiding infiltration of more water. Thus, in a dry year, water begins to fill the soil in almost the same quantity as in a wet year; then, if it rains only enough to fill the soil, runoff will be low. This is a cumulative process because part of water remains in the soil until the next rainy season. Therefore, if the previous year was dry, the soil water content at the beginning of the rainy season is low, and a higher volume of water will be necessary to fill the soil and cause runoff.

However, it is worth noting that areas of Hortonian runoff exist in sub-humid regions (i.e. Sudanian Africa) and, inversely, some "Hewlett-type" processes are observable in arid or semi-arid areas under certain circumstances (as in the west African Sahel). Although Cappus (1960) was the first to explain this kind of hydrologic functioning (widespread in template climates), we will call it "Hewlettian" runoff. It has also been thoroughly described by Dunne and Black (1970), and well studied by Ambroise (1999) in the Vosges mountains (France).

\section{Aim of the paper}

The aim of this paper is to show that using a simple deterministic model, NAZASM, it is possible to determine the spatial and temporal boundaries of Hortonian and Hewlettian functioning. We also aim to demonstrate the possible uses of this model throughout different geo-climatic areas.

\section{Materials and methods}

\section{Experimental data set and study area}

This study is based on data collected in four different areas of northern Mexico, more precisely in the states of Durango and Coahuila (Fig. 1). The entirety of this area is mostly or partially subjected to the North American Monsoon, during which precipitation is partially converted into stream flow (Gochis et al., 2006).

The first data collection site is a sub-humid area located in the Western Sierra Madre (SMO in this paper: Sierra Madre Occidental), the large mountainous range in the West of the country, $1500 \mathrm{~km}$ long and $200-300 \mathrm{~km}$ wide. This mountain typically receives between 450 and $1500 \mathrm{~mm}$ of annual rainfall; its internal slope, with eastern exposure, is dryer (rainfall ranges from 450 to $800 \mathrm{~mm}$ ) and gives its water to endoreic areas (the Bolson de Mapimi) and, northward, to the Rio Conchos, the main right bank tributary of the Rio Bravo/Grande. The experimental area is the upper Rio Sextin basin, in the north west of Durango State, on rural communities (ex-ejidos) in the municipalities of $\mathrm{El} \mathrm{Oro,}$ Tepehuanes and Guanacevi. This site ranges in altitude from 2000 to $3100 \mathrm{~m}$, with its experimental basins at altitude of $2100-2500 \mathrm{~m}$; its mean annual rainfall is around $600 \mathrm{~mm}$. This area is representative of the whole SMO, as it is composed of rhyolitic bedrocks, locally overlapped on the depressions by tufts and conglomerates. This mountain has significant slope gradients, except on its large summit

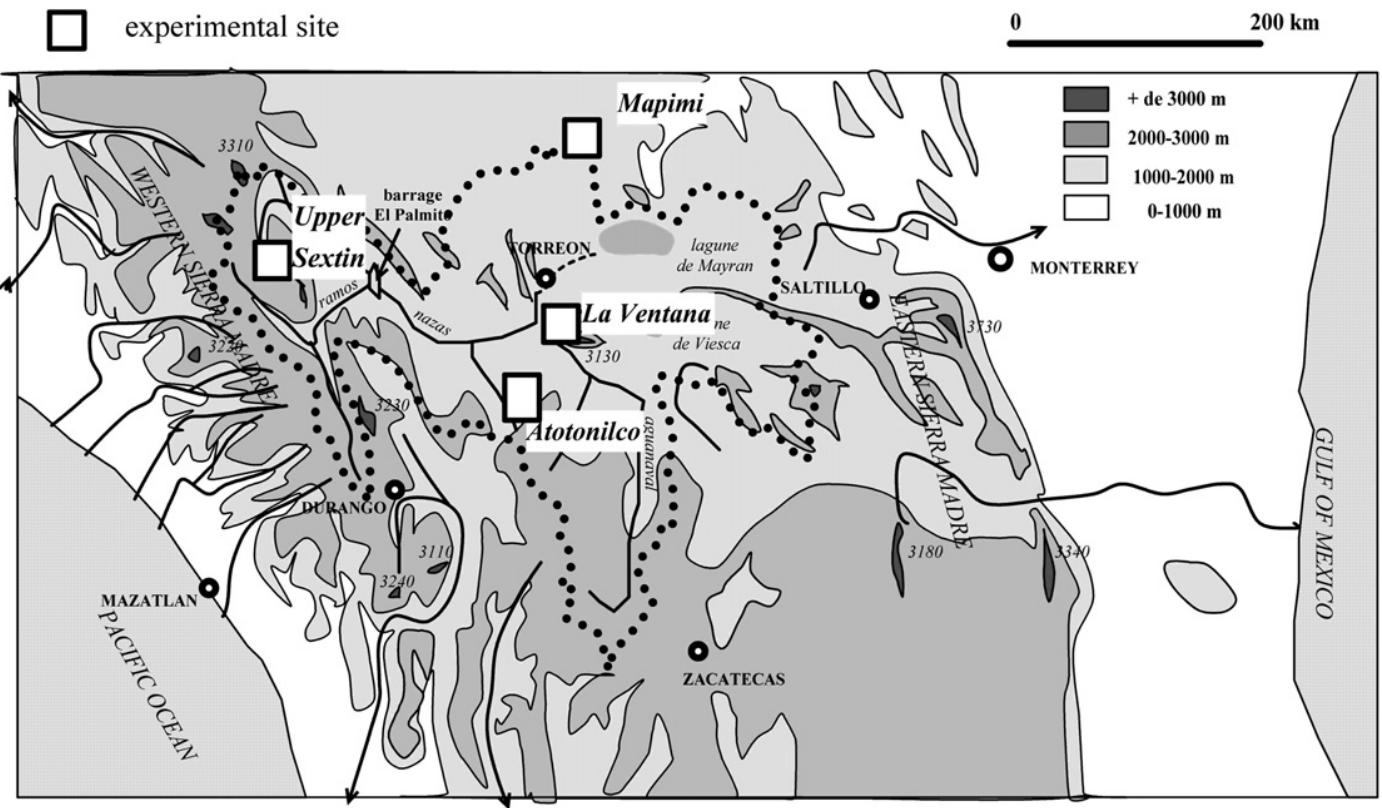

Figure 1 Location of experimental sites. 
plateau, 20-100 km wide, which is covered by natural pine/ oak forest. The slopes are covered with grasslands which originated when the natural forest was cleared (Descroix et al., 2001, 2002a).

The second experimental site is located in the piedmont of the SMO, composed of folds of limestone and marls materials, which create a landscape of hills ranging from 1800 to $2200 \mathrm{~m}$. These are the transition zone between the range (SMO) and the endoreic depression (Bolson de Mapimi, the southern part of Chihuahuan desert). Several more recent volcanic summits top the sedimentary cover in the upper part of the basin. The experimental area is located at Atotonilco, a large private ranch near Cuencamé, between the cities of Torreon and Durango (central southern part of Durango State), in the upper valley of Cuencamé River, a small tributary of the middle Rio Nazas (Fig. 1). Slopes have concave profiles with a high slope gradient only in the upper basin, since most of the landscape is composed of large glacis. The annual rainfall received at this experimental site is $450 \mathrm{~mm}$, the regional values ranging from $350 \mathrm{~mm}$ in the depressions to $500 \mathrm{~mm}$ on the summits. The natural vegetation was a dense bush (matorral with Juniperus spp., Opuntia spp., Acacia spp. and Prosopis spp.) which was completely cleared during the 20th century, to install durable pastures and grazing areas (Estrada-Avalos, 2000).

The third study area is located around the "desert laboratory" of the MAB (Man And Biosphere, UNESCO) Mapimi biosphere reserve, at the tri-junction of the Durango, Coahuila and Chihuahua States. This is an arid/semi-arid zone (annual rainfall is $275 \mathrm{~mm}$ on average, probably less in the bottom of endoreic depressions). It is a flat area composed of large, wide glacis and playas on sedimentary bedrocks, which range in altitude from 1100 to $1200 \mathrm{~m}$, and are dominated by small limestone or basaltic ranges with maximum altitudes of $1600-1800 \mathrm{~m}$. The vegetation is well adapted to aridity, with very few or no trees, but a relatively dense chaparral-type of cover dominated by Larrea tridentata and Prosopis spp., and large extensions of graminaceae with a dominance of Hilaria mutica and Sporobolus airoides. In spite of this cover, a large part of the surface is constituted of bare soils, explaining the high runoff coefficients (Delhoume, 1995).

The last site is the experimental catchment of La Ventana, located at the southern edge of the Bolson de Mapimi, in Coahuila State. This is a calcareous and steep range located in an arid region with poor matorral (edaphic drought is added to the climatic one), lightly covered with gobernadora (L. tridentata), ocotillo (Fouquieria splendens) and lechuguilla (Agave lechuguilla); it is located at the experimental agronomic station of "useful plants of the desert". Its altitude ranges between 1280 and $1730 \mathrm{~m}$ and its mean gradient slope is $25 \%$. Mean annual rainfall is $230 \mathrm{~mm}$.

There is a clear rainfall amount gradient from the SMO to the Mapimi desert (Fig. 2).

The data used in this study have been collected during the period of 1988-1998 in the four sites mentioned.

From 1988 to 1992 at the arid Chihuahuan desert sites, mentioned as "Mapimi" in this paper; this experimental site was equipped with five stream gauges ( 2 on catchments - MAPMIC and MAPCUEN in Tables 1 and 3 on Wischmeiertype $100 \mathrm{~m}^{2}$ plots, MAP1 to MAP3) and 78 rain gauges, two of which were recording gauges (Asseline, 1992).

From 1993 to 1996 at the calcareous arid catchment of La Ventana (La Ventana), where the equipment was composed of one stream gauge (VENT in Table 1) and nine raingauges, one of which was automatic (Descroix et al., 1997).

From 1996 to 1997 in the semi-arid region of Atotonilco (Atotonilco), where the experimental network included four stream gauges (CARB, VIEJ, TULL and PAST in Table 1) and 50 raingauges (6 of which 6 are recording ones), as well as 8 experimental $50 \mathrm{~m}^{2}$ plots (ATO 1 to ATO 8 in Table 1 ) (Estrada-Avalos, 2000).

From 1994 to 1998 in the mountainous, sub-humid experimental site of the SMO (Sierra or "Upper Nazas"' according

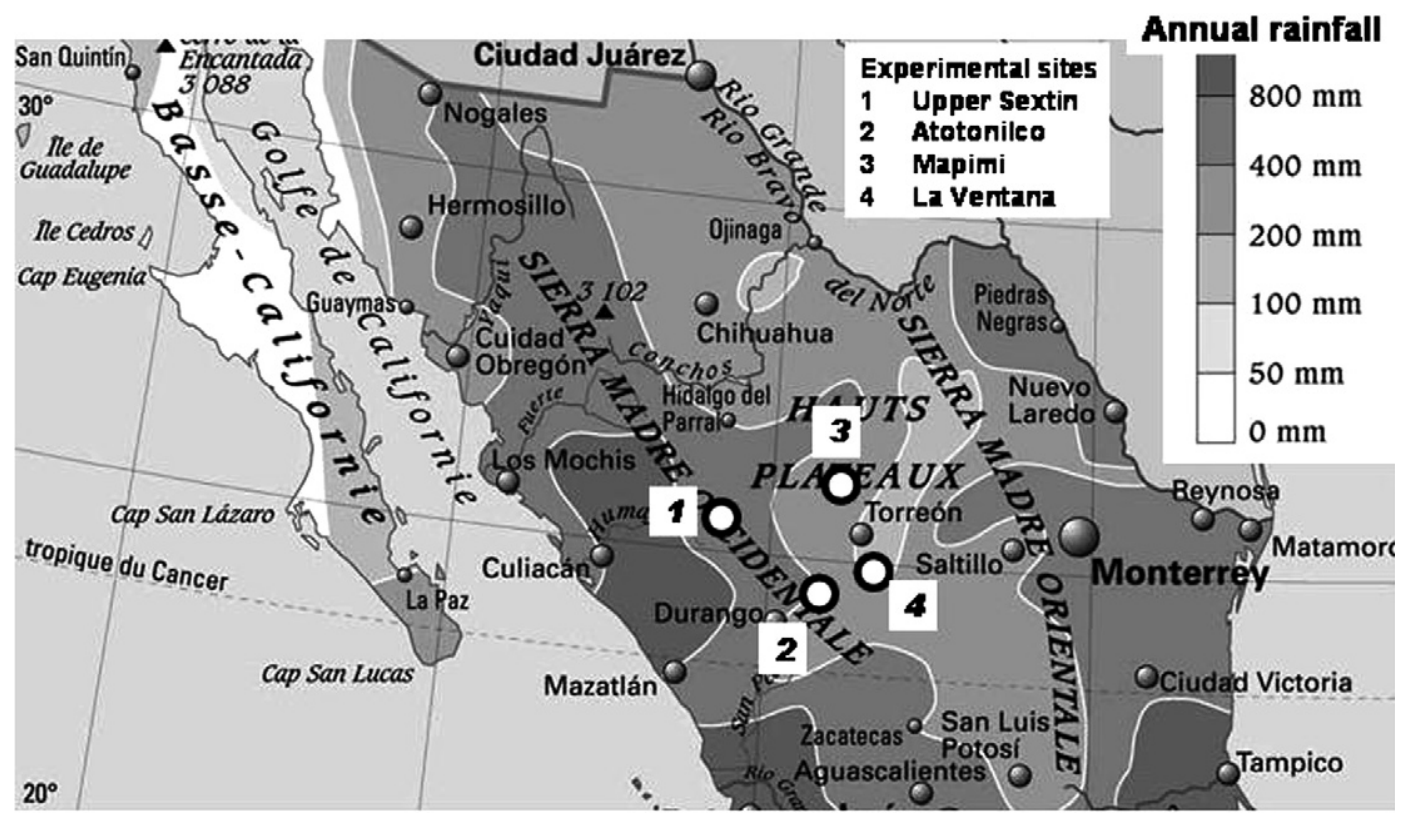

Figure 2 Spatial distribution of rainfall in Northern Mexico. 
Table 1 Characteristics of all the considered plots and catchments

\begin{tabular}{|c|c|c|c|c|c|c|c|}
\hline Name & Site & Area (ha) & Altitude min & Altitude max & $\begin{array}{l}\text { Mean annual } \\
\text { rainfall }(\mathrm{mm})\end{array}$ & Bare soil (\%) & Mean slope (\%) \\
\hline \multicolumn{8}{|l|}{ Plots } \\
\hline MAP1 & Mapimi & 0.0607 & 1180 & 1180 & 280 & 74 & 5.3 \\
\hline MAP2 & Mapimi & 0.0514 & 1160 & 1160 & 280 & 78 & 1.5 \\
\hline MAP3 & Mapimi & 0.0506 & 1145 & 1145 & 280 & 81 & 0.9 \\
\hline AT01 & Atotonilco & 0.0061 & 2125 & 2125 & 465 & 36 & 15 \\
\hline ATO2 & Atotonilco & 0.0062 & 2125 & 2125 & 465 & 31 & 18 \\
\hline ATO3 & Atotonilco & 0.0065 & 2205 & 2205 & 555 & 42 & 17 \\
\hline ATO4 & Atotonilco & 0.0065 & 2205 & 2205 & 555 & 17 & 18 \\
\hline ATO5 & Atotonilco & 0.0059 & 2105 & 2105 & 465 & 35 & 9 \\
\hline ATO6 & Atotonilco & 0.0062 & 2105 & 2105 & 465 & 64 & 8 \\
\hline AT07 & Atotonilco & 0.0053 & 2145 & 2145 & 555 & 14 & 11 \\
\hline АT08 & Atotonilco & 0.0068 & 2145 & 2145 & 555 & 22 & 11 \\
\hline MAN1 & Uppernazas & 0.005 & 2150 & 2150 & 575 & 3.1 & 20.7 \\
\hline MAN2 & Uppernazas & 0.005 & 2150 & 2150 & 575 & 4 & 13.6 \\
\hline MAN3 & Uppernazas & 0.005 & 2150 & 2150 & 575 & 1.5 & 12.9 \\
\hline MAN4 & Uppernazas & 0.005 & 2150 & 2150 & 575 & 0 & 23.2 \\
\hline MAN5 & Uppernazas & 0.005 & 2150 & 2150 & 575 & 0 & 10.2 \\
\hline MAN6 & Uppernazas & 0.0001 & 2150 & 2150 & 575 & 3.7 & 12.8 \\
\hline MAN7 & Uppernazas & 0.001 & 2150 & 2150 & 575 & 8 & 15.2 \\
\hline MAN8 & Uppernazas & 0.001 & 2150 & 2150 & 575 & 3.9 & 16.8 \\
\hline MAN9 & Uppernazas & 0.001 & 2150 & 2150 & 575 & 8.7 & 16.8 \\
\hline AGU1 & Uppernazas & 0.005 & 2250 & 2250 & 600 & 20.3 & 13.2 \\
\hline AGU2 & Uppernazas & 0.005 & 2250 & 2250 & 600 & 4.9 & 14.2 \\
\hline AGU3 & Uppernazas & 0.005 & 2250 & 2250 & 600 & 3.9 & 25.4 \\
\hline AGU4 & Uppernazas & 0.005 & 2250 & 2250 & 600 & 5.7 & 27.9 \\
\hline AGU5 & Uppernazas & 0.005 & 2250 & 2250 & 600 & 1 & 27 \\
\hline AGU6 & Uppernazas & 0.0001 & 2250 & 2250 & 600 & 0.6 & 14.2 \\
\hline ROSO & Uppernazas & 0.005 & 2500 & 2500 & 700 & 9.9 & 23.1 \\
\hline ROS1 & Uppernazas & 0.005 & 2500 & 2500 & 700 & 3.1 & 23.1 \\
\hline ROS2 & Uppernazas & 0.005 & 2500 & 2500 & 700 & 0 & 36.4 \\
\hline \multicolumn{8}{|c|}{ Catchments } \\
\hline MAPMIC & Mapimi & 6.64 & 1190 & 1390 & 280 & 34 & 50 \\
\hline MAPCUEN & Mapimi & 1170 & 1125 & 1390 & 280 & 90 & 4,8 \\
\hline CARB & Atotonilco & 106 & 2070 & 2260 & 474 & 29 & 20 \\
\hline VIEJ & Atotonilco & 176 & 2145 & 2400 & 543 & 43 & 22 \\
\hline TULL & Atotonilco & 398 & 1955 & 2180 & 468 & 43 & 15 \\
\hline PAST & Atotonilco & 168 & 2165 & 2220 & 484 & 36 & 5 \\
\hline VENT & Ventana & 300 & 1290 & 1730 & 250 & 15 & 25 \\
\hline PIL & Uppernazas & 5100 & 2100 & 2550 & 650 & 5 & 6,1 \\
\hline CUR & Uppernazas & 2180 & 2100 & 2350 & 600 & 2.5 & 6,6 \\
\hline ESM & Uppernazas & 128 & 2120 & 2250 & 600 & 10 & 13.3 \\
\hline MAN & Uppernazas & 310 & 2120 & 2350 & 575 & 10 & 4.6 \\
\hline POS & Uppernazas & 861 & 2200 & 2500 & 600 & 20 & 8.5 \\
\hline SEXTIN* & Uppernazas & 466,000 & 1800 & 3310 & 750 & 20 & 20 \\
\hline RAMOS* & Uppernazas & 713,000 & 1800 & 3150 & 750 & 10 & 17 \\
\hline
\end{tabular}

* These 2 last are not studied here and indicated only because they are mentioned in the paper.

to the context), which was equipped with 5 stream gauges (MAN, CUR, PIL, POS and ESM in Table 1), and 70 raingauges (7 of which were automatic); 18 experimental plots of 1,10 and $50 \mathrm{~m}^{2}$ were installed (MAN1 to MAN9; AGU1 to AGU6; ROSO to ROS2) (Descroix et al., 2002a).

The data set includes 10-156 rainy events (per year or group of years) depending on the plot or catchment (Tables 2 and 8). Since in certain cases, many years are merged, the lower number of values in these tables is 48 . For each event, rainfall amount, total runoff/stream flow amount (given as runoff depth in $\mathrm{mm}$ ) and the time elapsed since the end of the previous rainy event, were given by the measurement network. Bare soil proportion and mean slope were measured: on plots, each was measured in the field; for small basins, in the field but by sampling for land cover, with a small DEM for slopes; in large basins, bare soil \% were measured by satellite data (SPOT and Landsat scenes), mean slopes with a DEM. All the satellite scenes studies were 
"catchment heterogeneity" variable (Descroix et al., 2002a), will be set at 0.1 ; this does not change significantly the performance and sensitivity of the model, and it makes it significantly easier to use (but this explains why certain values are not exactly the same as those of the SMO mentioned in Descroix et al., 2002a). The accuracy of NAZASM is tested by a calibration/validation stage; furthermore, a sensitivity analysis of results to changes in parameters, based on $\mathrm{SI}_{10}$ index, is performed as suggested by De Roo (1993) and Giertz et al. (2006):

$\mathrm{SI}_{10}=\left(O_{\mathrm{p} 10}-O_{\mathrm{m} 10}\right) / O_{0}$

with

$O_{\mathrm{p} 10}$ model output with a $10 \%$ increase of the parameter value

$\mathrm{O}_{\mathrm{m} 10}$ model output with a $10 \%$ decrease of the parameter value

$\mathrm{O}_{0} \quad$ model output with base simulation

\section{Results}

Results are presented according to the main parameters of the model, which depend on the soil behaviour, and inversely, can describe and explain the spatial and temporal variability of these parameters. Parameters for the Sierra can be slightly different from those presented in the previous paper (Descroix et al., 2002a) due to re-initialisation of the model in order to include all the new data.

One hundred and eighteen calculations were made with data from the 13 catchments and 29 plots considered in this paper. Each calculation considers one plot or catchment for one year or a group of years; in certain cases, the calculation is duplicated with a second run taking into consideration only the events not caused by hurricanes.

\section{Spatial variability: regional analysis}

Runoff coefficient ( $K$ in Tables 2 and 3): This is clearly "soil surface feature' '-dependent: the highest value is found in Mapimi (37\%), followed by the Sierra (27\%), then those of Atotonilco (20\%) and, finally, the calcareous catchment in the arid environment of La Ventana, where edaphic and climatic droughts join to create a very low runoff coefficient $(0.07 \%)$ (Table 2$)$. Obviously, there is a great difference be- tween the plots' and the catchments' hydrological behaviour; the runoff coefficient of the former is significantly higher $(44 \%)$ than that of the latter $(7 \%)$ and this is valid in all environments, although it is lower on the sub-humid area (35\% on plots vs $12 \%$ on catchments). These values are the average of all values included Table 5 and Table 8 , without any statistical balancing (we presume here that the number of data is high enough to counterbalance any possible statistical aberration). Paradoxically, the higher runoff coefficients are measured in the desert; this is due to the high portion of crusted top soils. At the catchment scale, the highest values are observed in the Western Sierra Madre; however, as previously noticed and commonly observed (Descroix et al., 2002a), the runoff coefficient is lower on catchments (ranging from 1 to $52 \mathrm{~km}^{2}$ ) than on the plots, but it is also lower on these same catchments than in the large ones which include them: the Ramos basin (runoff coefficient 13\%) and the Sextin one (17\%) (Viramontes, 2000; Descroix et al., 2005a; Descroix et al., 2007). Otherwise, the correlation matrix (Table 3 ) shows that there is no correlation between the observed runoff coefficient on the one hand and the site parameters, rainfall annual amount, slope, altitude, proportion of bare soil and stone cover, on the other. This is not consistent with previous observations, but it is due here to the high heterogeneity of data set. We do not have enough plots (or catchments) in each geographic area to conduct a study of correlation with bare soil ratio; therefore we compare here (and in Figs. 3 and 4), for example, plots in the SMO (Western Sierra Madre) with catchments in the Chihuahuan desert; in a same region, we previously showed the relationship between bare soil ratio and erosion (or runoff, respectively) in the SMO with 17 experimental plots (see Descroix et al., 2001, in Catena).

$\alpha$ (in day $\left.^{-1}\right)$ is the inverse of the characteristic time of soil moisture depletion. Depending on the soil's water holding capacity ( $H_{\max }$, below), it is the most important parameter in the NAZASM model (see Fig. 5 in the Appendix). In addition to the soil's water holding capacity, it enables us to determine the soil's behaviour, and to separate plots or watersheds between the ones where Hortonian functioning dominates and the ones where Hewlettian runoff is the main process. There is an obvious separation between, the subhumid region (SMO), where $\alpha$ has a mean value of 0.08 , and the three other areas, where its value is near 0.5 (semi-arid and arid regions). This holds except for the

Table 3 Correlation matrix of different site characteristics with observed runoff coefficient $(K)$

\begin{tabular}{|c|c|c|c|c|c|c|c|c|}
\hline & Area (ha) & $\begin{array}{l}\text { Minimal } \\
\text { altitude }\end{array}$ & $\begin{array}{l}\text { Maximal } \\
\text { altitude }\end{array}$ & $\begin{array}{l}\text { Mean annual } \\
\text { rainfall }\end{array}$ & Bare soil (\%) & $\begin{array}{l}\text { Total } \\
\text { stoniness (\%) }\end{array}$ & Mean slope (\%) & $K$ \\
\hline Area ha & 1.00 & & & & & & & \\
\hline Alt min & -0.13 & 1.00 & & & & & & \\
\hline Alt max & 0.54 & 0.69 & 1.00 & & & & & \\
\hline Mean an rainfall & 0.37 & 0.81 & 0.90 & 1.00 & & & & \\
\hline Bare soil & -0.07 & -0.71 & -0.64 & -0.75 & 1.00 & & & \\
\hline Tot stone & -0.28 & -0.34 & -0.49 & -0.45 & 0.14 & 1.00 & & \\
\hline Mean slope \% & 0.05 & 0.17 & 0.18 & 0.17 & -0.39 & 0.10 & 1.00 & \\
\hline K & -0.12 & 0.00 & -0.27 & -0.03 & -0.02 & 0.23 & -0.29 & 1.00 \\
\hline
\end{tabular}




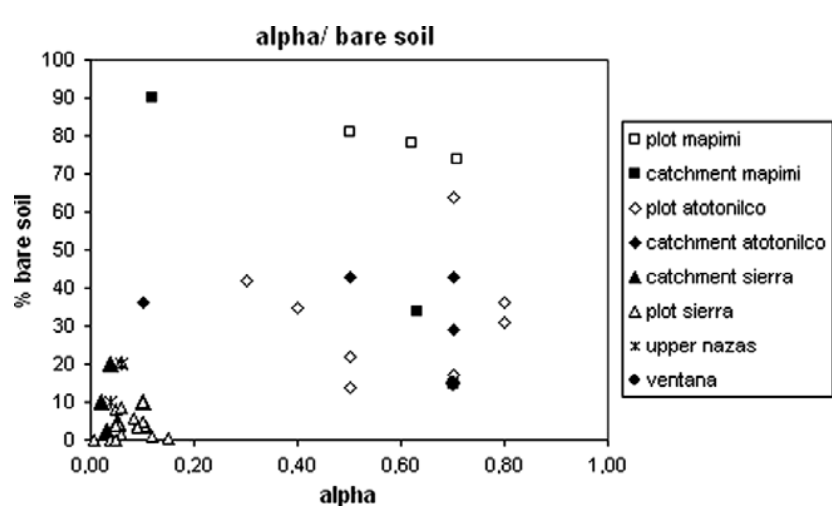

Figure 3 Classification of $\alpha$ by sites according to bare soil proportion in total area.

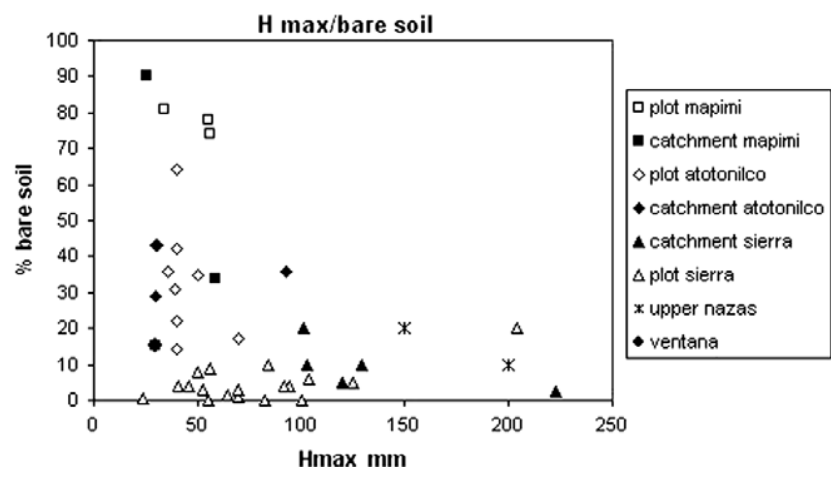

Figure 4 Classification of $H_{\max }$, by sites according to bare soil proportion in total area.

calcareous watershed of La Ventana where its value is 0.79 , proving evidence for a very fast reduction in soil water content. This parameter shows a relative constancy and robustness and its value is only slightly influenced by the size of the considered area; the value of $\alpha$ is only significantly higher on plots than on catchments in the Mapimi context (Tables 2,5 and 8).

$H_{\text {max }}$ is the maximum soil water holding capacity (here in $\mathrm{mm})$; there is a gradient ranging from wetter areas to drier ones. This theoretical value, calculated with the NAZASM model, is approximately $100 \mathrm{~mm}$ in the SMO, $46 \mathrm{~mm}$ in the semi-arid catchment of Atotonilco, and close to this value in the Chihuahuan desert $(50 \mathrm{~mm}$ at Mapimi, and only 30 in the limestone slope of La Ventana). This hierarchy of water holding capacity is obviously due not only to soil depth, which is higher in the Bolsón de Mapimi than in the SMO (because of topography), but also to the proportion of crusted soils (labelled as "bare soils" in Tables 1 and 3 and in Figs. 3 and 4) and the topography. At the Mapimi site, the $H_{\max }$ value for plots and catchments, respectively, are close, despite a strong difference in runoff coefficient: the soil elsewhere is the same, but the "mogotes" (vegetation strips of tiger bush) reduce runoff at the catchment scale. These values are significantly different from the soil water holding capacity measured in the field (Table 4).

$P_{\max }($ in $\mathrm{mm}$ ) is the maximum theoretical rainfall amount which does not produce runoff. There is, again, a great difference between the sub-humid area, where $P_{\max }$ is near
Table 4 The theoretical soil water holding capacity (TSWHC) in each experimental area

\begin{tabular}{lcll}
\hline & Soil depth $(\mathrm{cm})$ & Porosity $\%$ & TSWHC $(\mathrm{mm})$ \\
\hline Ventana & 10 & 40 & 40 \\
Mapimi & 120 & 35 & 420 \\
Atotonilco & 42 & 38 & 159.6 \\
SMO & 35 & 32 & 112 \\
\hline
\end{tabular}

TSWHC is obtained by multiplying the soil depth by its porosity (after Descroix et al., 1997; Viramontes and Descroix, 2002; Delhoume, 1995; Estrada-Avalos, 2000).

0.15 , and the three others, where it ranges from 0.41 in Atotonilco to approximately 0.55 in La Ventana and Mapimi. The size of impluvium (plot or catchment) only slightly influences the $P_{\max }$ values. In the mountains, runoff seems to appear earlier than in the arid and semi-arid areas; this is due to the non-segregation between Hortonian and Hewlettian runoff. Basins in the SMO can yield water with only $10 \mathrm{~mm}$ of rainfall; but it is mostly "saturation excess overland flow (SOF)", and it is characterized by the clearness of the water. $P_{\max }$ is lower in the mountains because of elevation, and also because, at times, low rainfall amount can yield runoff (Table 2 ).

The determination coefficient $\left(r^{2}\right)$ is monitored here to evaluate the capacity of the model to estimate the runoff yield of an area, and its relative performance in different configurations. There are no limitations in the use of NAZASM in either arid or sub-humid regions. The performance of the model (indicated by the determination coefficient of the rainfall-runoff predicted relationships) is always the same, although not absolute, highlighting the high spatial and temporal variability of the runoff conditions. However, the model is limited in its performance in the very dry La Ventana catchment, and in one of the plot of the SMO (ROS2), which is covered by a thick litter layer.

The area of the considered impluvium: the rainfall/runoff relation $P / R$ is better suited to plots than catchments. As previously indicated, the parameters of NAZASM do not have significantly different values depending on the size of the considered area, except for the runoff coefficient, what is known to be scale-dependent. $\alpha, P_{\max }$ and $H_{\max }$ have similar values on plots and on the catchments.

There have not yet been sufficient NAZASM model based studies to correlate parameters with some site's physical characteristics. However, here we use the proportion of the considered area which is classified as "bare soil" (commonly crusted soils), to classify $\alpha$ and $H_{\max }$. These characteristics are commonly considered to be a runoff yield important factor (Casenave and Valentin, 1989), and have been previously observed at the Sierra site (Descroix et al., 2001).

Fig. 3 allows to clearly distinguish the Sierra from the three other sites; the former has both low $\alpha$ and few bare soil. Plots and catchments of Atotonilco are very widespread, whereas the Mapimi plots have high $\alpha$ and bare soil cover. The Mapimi catchments have very different functionings: the large one (close to $12 \mathrm{~km}^{2}$ ) has a low $\alpha$ whereas the small one (almost $7 \mathrm{ha}$ ) has a high.

Fig. 4 differentiates the Sierra basins and plots from all the other sites because of their low bare soil cover, regard- 
less of the value of $H_{\max }$ is. All the other sites have low water holding capacity no matter what their bare soil proportion is.

To conclude, an environmental analysis demonstrated that the sub-humid environment in the SMO, in spite of an increase in crusted soil extension, clearly has some characteristics typical of a "Hewlettian" area,: low value of $\alpha$, high soil water holding capacity $\left(H_{\max }\right)$, reasonable runoff coefficients. Inversely, arid and semi-arid areas have "Hortonian' ' behaviour: high $\alpha$ and $H_{\max }$ values, great spatial variability of runoff coefficient and soil water holding capacity.

\section{Temporal variability: rainfall intensity and soil water holding capacity}

Intensity and duration of storms: It is worth noting that the duration of a storm is the first explanatory factor of soil water infiltration. Soil hydraulic conductivity is overall quite low in arid and semi-arid areas, due to the extension of crusted soils. Most of the annual rainfall is in the form of short storms with high intensity; only a small part of the rainfall can infiltrate since the soil water infiltration is exceeded by the rain's intensity, except in the Sierra Madre where the soil infiltrates higher quantities of rain water. However, in this area, land use changes lead to an increase in soil crusting, resulting in an increase in catchments where infiltration is reduced and which can become runoff yield areas. In both the SMO and the more arid areas, some events at the end of the rainy season, and some hurricanes, allow water to infiltrate in greater proportion, due to rainfall intensities lower than the soil's hydraulic conductivity.

Hurricanes could constitute a problem for the NAZASM model; in all the sites documented, they are characterized by long duration and low intensity rainfall. Hurricanes can last 2-4 days and rainfall amount can easily reach 40$60 \mathrm{~mm}$. The intensity is so low that there is never instant runoff; 24 or $48 \mathrm{~h}$ after the beginning of rainfall, a typical
"Hewlettian" runoff can appear, recognizable by clear streams, with very low sediment transport. However, if it appears, this runoff always gives runoff coefficients significantly lower than other rainfall events. Nevertheless, NAZASM seems to work correctly in spite of the distortion between two different kinds of rainy events. Whether the presence of hurricanes is taken into account or not, the performance of the model remains the same, in terms of determination coefficient of calculated vs observed runoff, in the arid $(0.73)$, the semi-arid $(0.61)$ and the sub-humid $(0.73)$ areas. However, the model's performance in the event of a hurricane is quite diminished in the La Ventana watershed, from 0.47 (a low value, due to the difficulty in predicting such an erratic runoff) to only 0.38 .

We considered here that runoff appears if the API instant value (the theoretical soil water content at the instant $t$ ) exceeds $H_{\max }$ (the soil water holding capacity). Then we studied the duration of this kind of situation at all the sites. The number of days with runoff is shown by region and named DRU in the Table 5.

- No excess: in certain places, the maximum value of API has never exceeded $H_{\max }$. This was the case in the semi-arid basins of Atotonilco, in the piedmont plots and in the Carboneras catchment.

- In most of the other arid or semi-arid sites, API exceed $H_{\text {max }}$ for less than 1 day. However, the largest catchment of Mapimi site and the Pastelero basin at Atotonilco have had on average 2 days with this "theoretical runoff capacity',.

- In the Western Sierra Madre, only the La Posta basin has never known excess of API (however, observations were only made in this basin over the course of 1 year, 1997, a dry year). The other plots and watersheds have values ranging from 0.33 (Pilitas catchment) and 12.25 (the Manga catchment), and from 4.6 (Manga plots) to 6.17 (Rosilla plots).

Table 5 Occurrence of days with possible runoff events and theoretical "wet days"

\begin{tabular}{|c|c|c|c|c|c|c|c|c|}
\hline & $\alpha$ & $H_{\max }$ & $A P I_{\max }$ & $\mathrm{API} / H_{\max }$ & DRU & DWE & HUR & $K$ \\
\hline \multicolumn{9}{|l|}{ Total total } \\
\hline Mean Mapimi & 0.51 & 50.45 & 17.56 & 0.35 & 1.03 & 4.24 & 2.34 & 0.2900 \\
\hline Mean Ventana & 0.79 & 28.13 & 15.08 & 0.54 & 0.40 & 4.80 & 0.00 & 0.0006 \\
\hline Mean Atotonilco & 0.56 & 38.26 & 28.47 & 0.81 & 0.74 & 6.31 & 2.94 & 0.1683 \\
\hline Mean Sierra & 0.08 & 93.55 & 97.22 & 1.04 & 5.59 & 20.96 & 0.22 & 0.2421 \\
\hline Catchments & 0.37 & 68.31 & 53.96 & 0.79 & 2.21 & 10.90 & 1.95 & 0.0471 \\
\hline Plots & 0.29 & 68.27 & 58.48 & 0.86 & 3.23 & 11.40 & 0.75 & 0.3707 \\
\hline \multicolumn{9}{|l|}{ Mapimi } \\
\hline Catchments & 0.40 & 52.93 & 24.60 & 0.46 & 1.27 & 5.73 & 3.91 & 0.0387 \\
\hline Plots & 0.61 & 48.39 & 13.26 & 0.27 & 0.89 & 3.33 & 1.39 & 0.4906 \\
\hline \multicolumn{9}{|l|}{ Atotonilco } \\
\hline Catchments & 0.55 & 33.82 & 28.64 & 0.84 & 1.00 & 7.63 & 3.38 & 0.0404 \\
\hline Plots & 0.59 & 44.38 & 28.30 & 0.64 & 0.13 & 5.00 & 2.50 & 0.2963 \\
\hline \multicolumn{9}{|l|}{ Sierra } \\
\hline Catchments & 0.09 & 113.65 & 110.32 & 0.97 & 6.25 & 27.40 & 0.60 & 0.0747 \\
\hline Plots & 0.08 & 83.11 & 89.52 & 1.08 & 5.21 & 17.18 & 0.00 & 0.3285 \\
\hline
\end{tabular}

$K$ is runoff coefficient; the other parameters are described in the text. 
As had been the case for the $H_{\max }$ values, the sub-humid site is yet a gain segregated from the other three. On average, in the sub-humid Western Sierra Madre, API exceeds $H_{\max } 5$ or 6 days a year, instead of $0.5-1$ day a year like in the arid or semi-arid sites. When we create a theoretical "wet day" (DWE, Table 5) where the API value reaches $50 \%$ of the $H_{\max }$ value, the same gap appears between the mountain ( 21 "wet days" a year in average) and the other sites (4.24 at Mapimi; 4.8 at La Ventana; 6.31 at Atotonilco)

Paradoxically, in the latter, the role of hurricanes is higher than in the former. The "HUR" (Table 5) column indicates the number of days with $\mathrm{API} / H_{\max }$ surplus that are caused by hurricanes.

In two of the experimental sites (Sierra, Atotonilco), it is worth noting that results could be slightly biased by the severe drought that affected the whole of northern Mexico from 1992 to 2004. Within this period, and during the measuring period (see "Materials and methods") the year 1996 was slightly wet, with rainfall amounts $10-20 \%$ above the average in all of the Nazas basin. This allowed us to improve our knowledge on soils and basin's hydrological behaviour in all kinds of situations. Three observations are to be made:

- The abundant rainfall of 1996 triggered most of the "Hewlett" type runoff observed in our sampling period, in both the sub-humid and the semi-arid experimental sites.

- Due to the four previous dry years (1991 was over-abundant, as was the winter of 1991-1992, marked by an ENSO - El Niño Southern Oscillation - event), the soil water content at the beginning of the monsoon of 1996 was very low, and the rainfall amount in this rainy season did not suffice to fill the soil at its "common" water content.

- Peasants in the Western Sierra Madre said in 1996 that it was a "normal year" as opposed to the four previous ones. Overland flow and stream flow were similar in their memory to that of years ago. It is always and anywhere dangerous to be confident with this kind of observations, but it is consistent with rainfall recording (Table 6); the annual mean rainfall amount at La Cienega de Escobar meteo station is $584 \mathrm{~mm}(1965-2000)$; it is located $15 \mathrm{~km}$ westward from the experimental area. Thus this could confirm that the environment in the Western Sierra Madre is "Hewlett-type".

- During the 1994-1997 period of measurement, no winter precipitation occurred. Winter rainfall (see above about the 1991-1992 winter), commonly ENSO-dependent, produces low intensity and long duration rainfall, similar to the hurricane originated events. More recently, during the 2001-2002 winter, reservoir dams were filled by runoff caused by to this kind of event, as they were during the 1991-1992 winter: runoff coefficients are low at the beginning, but Hewlettian processes can appear due to the long duration of events and low PE values due to low temperatures.

The time variables of $\alpha$ are (1) the rainfall amount in the considered year (Table 7); this is normally a robust and constant value for a given plot or a given watershed. $H_{\max }$ and $\alpha$ are both linked to the maximum value of API, (2) the number of days annually "with runoff" or "wet". This is slightly related to both the annual rainfall amount (positively) and the parameter $\alpha$. The latter is definitively not correlated with any runoff coefficient.

The accuracy of the NAZASM model is shown in Table 8 by the calibration and validation analysis; all the results are quite acceptable, except for those of the La Ventana catchment; in the latter, only 7 rainy events triggered runoff, one of which reached $90 \%$ of the total discharge measured in 4 years in this catchment. As a result, this sole event is creating a rainfall/runoff correlation; it is included in one of the samples for the calibration/validation test; in the other sample, no correlation is observed due to the erratic rainfall and rainfall-runoff generation.

The sensitivity of model results to changes in the involved parameters is presented in Table 9 . The less sensitive parameter is clearly $\alpha$ and the more sensitive one is $K_{\max }$; $P_{\max }$ and $H_{\max }$ are on an intermediate position.

\section{Discussion}

\section{On the parameters}

The comparative analysis of $\alpha$ parameter provides results which are consistent with data values in the great basins (Sextin and Ramos); the latter are, respectively, 0.04 and 0.06 , and it has been noticed that these values are subject to a slow but certain evolution (Viramontes, 2000; Viramontes and Descroix, 2003): they are increasing (from the 1970s to the 1990s), providing an evidence for a reduction in soil water holding capacity which can be attributed to the land use changes.

The absolute value of $\alpha$ parameter is a good indicator of the hydrological behaviour of a basin or a plot. Traditionally, the "Sahelian" authors (Casenave and Valentin, 1989; Chevalier, 1983; Albergel, 1987) used the value of 0.5 for these semi-arid areas; this value is clearly consistent with a Horton-type runoff region. But these authors did not publish investigations on possible variations in this parameter, to use either as an indicator of runoff behaviour or of

Table 6 Rainfall amount $(\mathrm{mm})$ in the experimental sites of the Western Sierra Madre: representativeness of the "wet" year 1996

\begin{tabular}{|c|c|c|c|c|c|c|c|c|c|c|}
\hline Experimental site & 1991 & 1992 & 1993 & 1994 & 1995 & 1996 & 1997 & 1998 & 1999 & 2000 \\
\hline Rosilla & & & & 345 & 360 & 612 & 339 & 365 & & \\
\hline Aguaje & & & & 295 & 324 & 690 & 298 & 320 & & \\
\hline Manga & & & & 234 & 284 & 602 & 322 & 272 & & \\
\hline Cienega de Escobar met station & 428 & 432 & 512 & 370 & 490 & 694 & 460 & 410 & 365 & 445 \\
\hline
\end{tabular}


Table 7 Correlation matrix explaining temporal variables of Nazasm model parameters

\begin{tabular}{|c|c|c|c|c|c|c|c|c|c|c|c|c|c|}
\hline & $R$ & $\alpha$ & $K_{\max }$ & $P_{\max }$ & $H_{\max }$ & $K$ & $\mathrm{Ksr}$ & $\mathrm{Kmd}$ & APIX & $\mathrm{AP} / \mathrm{H}$ & DRU & DWE & HUR \\
\hline$R$ & 1.00 & & & & & & & & & & & & \\
\hline$\alpha$ & -0.47 & 1.00 & & & & & & & & & & & \\
\hline$K_{\max }$ & 0.05 & 0.01 & 1.00 & & & & & & & & & & \\
\hline$P_{\max }$ & -0.15 & 0.58 & 0.05 & 1.00 & & & & & & & & & \\
\hline$H_{\max }$ & 0.58 & -0.59 & -0.10 & -0.49 & 1.00 & & & & & & & & \\
\hline K & 0.06 & -0.04 & 0.90 & 0.10 & -0.11 & 1.00 & & & & & & & \\
\hline $\mathrm{Ksr}$ & -0.02 & -0.07 & 0.82 & -0.07 & -0.14 & 0.81 & 1.00 & & & & & & \\
\hline Kmd & 0.04 & -0.03 & 0.92 & 0.10 & -0.13 & 0.98 & 0.80 & 1.00 & & & & & \\
\hline APIx & 0.66 & -0.58 & -0.02 & -0.28 & 0.69 & 0.08 & -0.11 & 0.03 & 1.00 & & & & \\
\hline $\mathrm{AP} / H$ & 0.19 & -0.21 & -0.02 & 0.12 & -0.17 & 0.11 & -0.06 & 0.09 & 0.33 & 1.00 & & & \\
\hline DRU & 0.33 & -0.34 & 0.03 & -0.10 & 0.13 & 0.14 & -0.01 & 0.13 & 0.52 & 0.64 & 1.00 & & \\
\hline DWE & 0.50 & -0.52 & -0.01 & -0.31 & 0.35 & 0.06 & 0.01 & 0.06 & 0.57 & 0.53 & 0.72 & 1.00 & \\
\hline HUR & 0.04 & 0.09 & -0.14 & 0.43 & -0.15 & -0.08 & -0.09 & -0.07 & -0.13 & 0.08 & -0.09 & -0.01 & 1.00 \\
\hline
\end{tabular}

$R-$ annual rainfall.

$\alpha$ - inverse of the characteristic time of soil moisture depletion.

$K-$ measured runoff coefficient (runoff/rainfall).

$\mathrm{Ksr}$ - square root of runoff coefficient (runoff square root/rainfall).

Kmd - runoff coefficient calculated by Nazasm model.

APIx - maximum value of API within the year.

$\mathrm{AP} / H$ - ratio of $H_{\text {max }}$ by API of the current day.

DRU - number of days with runoff.

DWE - number of wet days ( $50 \% H_{\max }$ filled by API).

HUR - number of wet days due to hurricane.

Table 8 Results of calibration/validation of NAZASM model

\begin{tabular}{|c|c|c|c|c|c|c|c|c|c|c|c|c|}
\hline & \multirow[t]{2}{*}{ Year } & \multirow[t]{2}{*}{$r^{2}$ model } & \multirow[t]{2}{*}{$r^{2} \mathrm{RC} / \mathrm{RO}$} & \multirow[t]{2}{*}{$\mathrm{Nb}$} & \multicolumn{4}{|c|}{ Calibration } & \multicolumn{4}{|c|}{ Validation } \\
\hline & & & & & $r^{2}$ calib & $x \mathrm{RC} / \mathrm{RO}$ & $r^{2} \mathrm{RC} / \mathrm{RO}$ & $\mathrm{Nb}$ & $r^{2}$ valid & $x \mathrm{RC} / \mathrm{RO}$ & $r^{2} \mathrm{RC} / \mathrm{RO}$ & $\mathrm{Nb}$ \\
\hline MAP1 & $1988-1992$ & 0.96 & 0.79 & 102 & 0.97 & 1 & 0.78 & 51 & 0.95 & 1.05 & 0.81 & 51 \\
\hline MAP2 & 1988-1992 & 0.86 & 0.76 & 102 & 0.87 & 1 & 0.74 & 51 & 0.85 & 1 & 0.8 & 51 \\
\hline MAP3 & 1988-1992 & 0.98 & 0.88 & 102 & 0.98 & 1 & 0.86 & 51 & 0.98 & 1 & 0.88 & 51 \\
\hline MAPMIC & $1988-1992$ & 0.93 & 0.36 & 102 & 0.98 & 1.01 & 0.49 & 51 & 0.88 & 1 & 0.5 & 51 \\
\hline MAPCUEN & 1988-1991 & 0.78 & 0.55 & 92 & 0.83 & 0.99 & 0.73 & 45 & 0.89 & 1 & 0.6 & 45 \\
\hline AT01 & 1996 & 0.99 & 0.68 & 50 & 0.97 & 0.99 & 0.64 & 25 & 0.98 & 1 & 0.73 & 25 \\
\hline ATO2 & 1996 & 0.90 & 0.60 & 50 & 0.98 & 1 & 0.56 & 25 & 0.92 & 1.01 & 0.69 & 25 \\
\hline ATO3 & 1996 & 0.99 & 0.74 & 48 & 0.94 & 1.00 & 0.78 & 24 & 0.95 & 1 & 0.84 & 25 \\
\hline ATO4 & 1996 & 0.95 & 0.62 & 48 & 0.94 & 0.99 & 0.46 & 24 & 0.95 & 1.01 & 0.78 & 24 \\
\hline ATO5 & 1996 & 0.97 & 0.77 & 50 & 0.97 & 1 & 0.75 & 25 & 0.96 & 1 & 0.8 & 25 \\
\hline ATO6 & 1996 & 0.90 & 0.60 & 50 & 0.90 & 1 & 0.50 & 25 & 0.9 & 1 & 0.69 & 25 \\
\hline ATO7 & 1996 & 0.99 & 0.78 & 48 & 0.98 & 1.00 & 0.76 & 24 & 0.99 & 1.03 & 0.79 & 24 \\
\hline AT08 & 1996 & 0.94 & 0.73 & 50 & 0.9 & 0.99 & 0.70 & 25 & 0.9 & 1 & 0.81 & 25 \\
\hline CARB & $1996 / 1997$ & 0.98 & 0.50 & 98 & 0.98 & 1 & 0.48 & 49 & 0.99 & 0.98 & 0.67 & 49 \\
\hline VIEJ & $1996 / 1997$ & 0.99 & 0.65 & 95 & 0.99 & 0.99 & 0.57 & 48 & 0.99 & 1 & 0.79 & 47 \\
\hline TULL & $1996 / 1997$ & 0.98 & 0.50 & 95 & 0.98 & 1 & 0.55 & 48 & 0.96 & 1 & 0.53 & 47 \\
\hline PAST & $1996 / 1997$ & 0.89 & 0.45 & 101 & 0.90 & 0.99 & 0.61 & 50 & 0.92 & 1 & 0.52 & 51 \\
\hline VENT & 1993-1996 & 0.95 & 0.64 & 89 & 1.00 & 0.99 & 0.63 & 45 & 0.98 & 0.01 & 0.15 & 45 \\
\hline PIL & 1995-1997 & 0.73 & 0.61 & 117 & 0.76 & 0.90 & 0.61 & 59 & 0.81 & 0.90 & 0.61 & 58 \\
\hline CUR & 1995-1998 & 0.71 & 0.90 & 147 & 0.81 & 1.00 & 0.90 & 74 & 0.64 & 1.00 & 0.90 & 73 \\
\hline ESM & 1995-1998 & 0.67 & 0.72 & 136 & 0.66 & 1.00 & 0.72 & 68 & 0.72 & 1.00 & 0.72 & 68 \\
\hline MAN & 1995-1998 & 0.93 & 0.85 & 156 & 0.75 & 1.01 & 0.85 & 79 & 0.76 & 1.01 & 0.85 & 78 \\
\hline AGU2 & $1996-1998$ & 1.00 & 0.68 & 111 & 0.63 & 1.00 & 0.68 & 56 & 0.73 & 1.00 & 0.68 & 56 \\
\hline
\end{tabular}

$r^{2}$ is the determination coefficient.

$x$ is the value of RC/RO ratio (observed vs calculated runoff).

$\mathrm{RC} / \mathrm{RO}$ is the observed vs calculated runoff depth relationship.

$\mathrm{Nb}$ is the number of rainy events considered at each plot/year or catchment/year. 


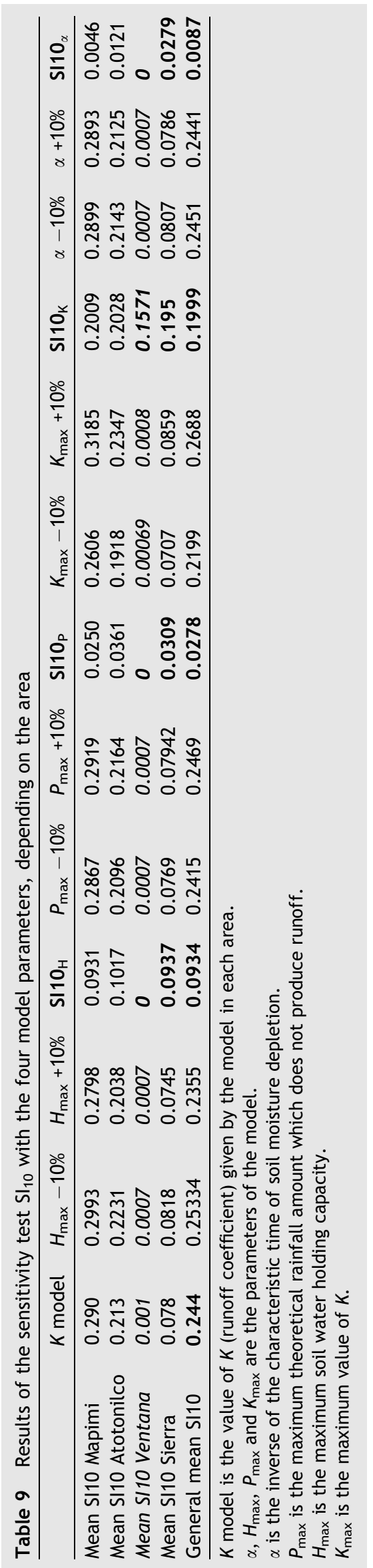

soil water holding capacity. In the North of Mexico, whatever the considered area is, 0.5 is also adapted for Hortonian environments, and 0.01 for Hewlettian ones, in accordance with the results presented here. Thus, all the intermediate values can be found, depending on the proportion of Horton-type runoff areas. Albergel (1987) justifies the use of this fixed value by previous experiments, all located in the Sahel, in which it was demonstrated that only few centimetres of top soils are wetted annually in this region.

The $H_{\max }$ parameter (soil water holding capacity) measured in the Sierra Madre is slightly lower than calculated by Viramontes (2000) for the two great catchments: $195 \mathrm{~mm}$ for the Rio Ramos basin $\left(7130 \mathrm{~km}^{2}\right)$ and $130 \mathrm{~mm}$ for the Rio Sextin basin $\left(4660 \mathrm{~km}^{2}\right)$. Only the Cura catchments have an $H_{\max }$ value close to Viramontes calculation $(154 \mathrm{~mm})$. The other experimental catchments have $H_{\max }$ values near $100 \mathrm{~mm}$; the plots have lower values, approximately $80 \mathrm{~mm}$ (see Table 2). The latter values are consistent with those previously measured through soil hydrodynamic characteristics (total porosity, bulk density, soil depth and hydraulic conductivity) by Viramontes (1995): $75 \mathrm{~mm}$ for basins located on tufts and conglomerates outcrops, and $110-134 \mathrm{~mm}$ for ignimbritic catchments. Variations on $H_{\max }$ value on the same plot or catchments from one year to another can be explained by total rainfall amounts; it is commonly admitted that soil water conductivity in an unsaturated area increases with soil water content to values close to the saturation point. In Mapimi, Delhoume (1995) estimated the soil water holding capacity to be between 80 and $200 \mathrm{~mm}$ depending on the slope gradient. With the time scale of a rainy season, it was estimated that runoff began only after $150 \mathrm{~mm}$ of rainfall in the SMO, as compared to the estimation of $100 \mathrm{~mm}$ at the semi-arid Atotonilco experimental catchment (Estrada-Avalos, 2000). The theoretical soil water holding capacity can be estimated, as showed in Table 4 in detail.

Soil water holding capacity is generally first linked to soil depth; but here, as in most arid or semi-arid areas, soil crusting disrupts this hierarchy. The Sierra has higher water holding capacity despite its thinner soils because water can infiltrate (better soil structure, lower bulk density, more roots, more litter, more stones, more rainfall events with lower time elapsed between two events) in the whole soil depth. In arid and semi-arid areas (typically in Mapimi), soils are deeper (several meters), but are also more clayey and generally crusted; Delhoume (1995) observed that the wetted layer, after a rainy event in Mapimi, ranges from 1 to $3 \mathrm{~cm}$.

\section{On the scale effect}

As it has been previously described (Descroix et al., 2005a), there is not always a negative correlation between the runoff coefficient and the catchment size. This corresponds with observations made, northward of the Mapimi desert, at the Walnut Gulch experimental watershed, in Arizona, where "watershed runoff response becomes more nonlinear with increasing watershed scale, with a critical transition threshold area occurring roughly around 50 ha', (Goodrich et al., 1997). 
However, there is clearly a decrease in runoff coefficient with the rise in considered area, up to $50 \mathrm{~km}^{2}$; this is also due, particularly in semi-arid areas, to water run-on into the beds of the "arroyos". This phenomenon was also described in the Sahel by Esteves and Lapetite (2003).

It is not easy to use a conceptual model for a scientific question based on the variety of runoff patterns in a particular region. A model based on Hortonian runoff principles could be inadequate for catchments where runoff is dominated by rapid saturated subsurface flow or variable source area-type runoff (Hughes, 1994); however, the NAZASM model, made for exploring the Hortonian runoff, is suitable until its boundaries, which it allows us to determine. It should not be applied in the Sahel where Peugeot et al. (2003) concluded that "soil moisture at storm onset is of secondary importance for the rainfall-runoff process in the area".

\section{Intensity and duration of rainfall}

Runoff can occur after 1 or $2 \mathrm{~mm}$ rainfall in crusted soils in the Western Sierra Madre, as well as in the Sahel. Inversely, sometimes rain intensity does not exceed the low soil infiltration capacity; in this case, if the rain lasts more than several hours, a Hewlettian runoff can appear with clear waters. Water flows for some meters until the soil is completely saturated; then, runoff appears and can last several more days due to the great volume stored in the soil.

The difficulty in predicting runoff yield is partially due to the high spatial variability of saturated hydraulic conductivity (already mentioned in Descroix et al., 2002b); this was noticed previously by Woolhiser et al. (1996) who observed that runoff hydrographs are strongly affected by trends in hydraulic conductivity, particularly with small runoff events. This problem is similar to the one caused here by the low runoff coefficient of autumn hurricane-degraded type precipitations.

\section{Conclusion}

Although it is easy to determine on the field if a slope, a plot, or a catchment has Hortonian or Hewlettian behaviour, we can conclude that, as with all hydrological problematics, this is also scale-dependent.

The NAZASM model seems to indicate that despite a low difference in annual rainfall amount, runoff in the Sierra Madre is Hewlett-type, at least on forest and non degraded savannas and grasslands, whereas it is Horton-type in the semi-arid site of Atotonilco and, a fortiori, in the two arid experimental sites. But clearly, at the plot, and sometimes at the small catchment, scale, there are areas where Horton-type runoff dominates in the Western Sierra Madre, and certain instances where Hewlett-type hydrological behaviour is noticeable in semi-arid areas. At the basin scale, infiltration and temporary ponding areas increase the soil water holding capacity even in Hortonian zones.

Due to the supposed representativeness of our experimental sites, it is possible to extend our observations to the whole of North Central Mexico: probably all of the area included between the Sierra Madre Occidental and the Sierra Madre Oriental, composed of great endoreic depressions with extended playas and glacis, cut by limestone (like La
Ventana) or basaltic ranges (like Cerro San Ignacio at Mapimi), has Hortonian hydrological behaviour, whereas the former mountain is obviously characterized by "Hewletttype"' runoff. We did not investigate the Eastern Sierra Madre, which is mostly calcareous, but it is likely that higher parts of it, covered by pine forest, have a Hewlettian hydrology, whereas internal slopes of the Sierra will have a hydrological functioning similar to those of the La Ventana basin.

\section{Acknowledgements}

We are grateful to the ECOS ANUIES (Franco-Mexican Universitary Cooperation) program for supporting this research in the fields from 2001 to 2005 . We acknowledge the IRD (Institut de Recherche pour le Développement) for funding these studies, and the CENID RASPA (INIFAP Mexico) for its generous material support.

\section{Appendix. The Nazasm model (in Descroix et al., 2002a)}

(i) The following rainfall-runoff relation is assumed to hold for any rainy event, $n$ :

$$
\sqrt{\mathrm{Rd}_{n}}=K_{n}\left(P_{n}-P_{0 n}\right) \quad \text { with } P_{n}>P_{0 n}
$$

where $\mathrm{Rd}_{n}$ and $P_{n}$ are the runoff depth and the rainfall amount, respectively, both expressed in $\mathrm{mm}$. $K_{n}$ (in $\mathrm{mm}^{-1 / 2}$ ) is a parameter depending on the soil surface hydraulic conductivity, on the catchment area and on the proportion of the catchment contributing to runoff. $P_{0 n}$ $(\mathrm{mm})$ is the rainfall below which there is no runoff.

Because it has been observed that all the measured values of $\sqrt{\operatorname{Rd}_{n}}$ and $P_{n}$ were included between two straight lines, $K_{n}$ can be expressed as

$K_{n}=K_{\min }+\left[\left(K_{\max }-K_{\min }\right) /\left(P_{0 \max }-P_{0 \min }\right)\right] *\left(P_{0 \max }-P_{0 n}\right)$

where $K_{\max }, K_{\min }, P_{0 \max }$ and $P_{0 \min }$ correspond to the maximum and minimum values, respectively, of $K$ and $P_{0 n}$ for either the plots or the catchments.

(ii) By assimilating the soil to a reservoir, $P_{0 n}$ can be expressed as

$P_{0 n}=C\left(H_{\max }-\mathrm{API}_{n}\right)$ with $\mathrm{API}_{n} \leqslant H_{\max }$

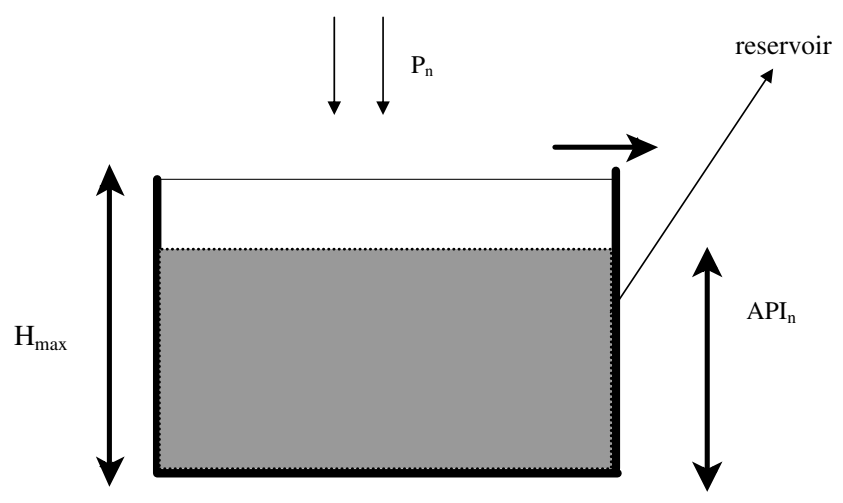

Figure 5 Functioning of NAZASM model. 
where $C$ is a parameter taking into account most likely rainfall intensity and indirectly the catchment heterogeneity, the water storage of the soil surface (including vegetation and litter) and the mechanical effect of raindrops on the soil. $H_{\max }$ is the maximum water storage of the reservoir $(\mathrm{mm})$ and $A P I_{n}(\mathrm{~mm})$ is its actual level at a given time.

(iii) Following the definition of the antecedent precipitation index (Kohler and Lindsey, 1951; Chevalier, 1983), $\mathrm{API}_{n}$ is calculated as

$\mathrm{API}_{n}=\left(\mathrm{API}_{n-1}+P_{n-1}\right) \exp (-\alpha \Delta t)$

where $\Delta t=t_{n}-t_{n-1}$ is the time (day and/or fraction of day) elapsed between the end of the previous rain event $P_{n-1}$ and the beginning of the current one $\left(\mathrm{P}_{n}\right)$.

The parameter $\alpha\left(\right.$ day $\left.^{-1}\right)$ is the inverse of the characteristic time of soil moisture depletion.

Introducing Eq. (4) into Eq. (3) and then into Eq. (1), gives

$\sqrt{\mathrm{Rd}_{n}}=K_{n}\left\{P_{n}-C\left[H_{\max }-\left(\mathrm{API}_{n-1}+P_{n-1}\right) \exp \left(-\alpha\left(t_{n}-t_{n-1}\right)\right)\right]\right\}$

The model (Eq. (5)) has seven parameters $\left(C, H_{\max }, \alpha, K_{\max }, K_{\min }, P_{0 \max }, P_{0 \min }\right)$ to be determined. This was achieved by splitting the time series of observed $\left(P_{n}, \mathrm{Rd}_{n}\right)$ values in two parts (one event out of two): one half being used for the calibration of the parameters by best fitting between calculated and measured values of runoff depths, and the other one for the validation, the values of the parameters being kept unchanged.

The model is initialised at the beginning of the rainy season where $\mathrm{API}_{0}$ is assumed to be zero.

\section{References}

Albergel, J., 1987. Genèse et prédétermination des crues au Burkina Faso. Du $\mathrm{m}^{2}$ au $\mathrm{km}_{2}$, étude des paramètres hydrologiques et de leur évolution. PhD, coll. Etudes et Thèses, éditions de l'IRD, Paris, 333 p.

Amani., A, Nguetora, M., 2002. Evidence d'une modification du régime hydrologique du fleuve Niger à Niamey. In: Van Lannen, H., Demuth, S. (Eds.) FRIEND 2002 Regional Hydrology: Bridging the Gap Between Research and Practice. Proc. of Friend Conf, Cape Town, S.A IAHS Pub. 274, pp. 449-456.

Ambroise, B., 1999. Genèse des débits dans les petits bassins versants ruraux en milieu tempéré; 1 - processus et facteurs. Revue des Sciences de l'Eau 4, 471-495.

Asseline, J., 1992. Métodos y técnicas empleadas para los estudios hidroedafológicos en la Reserva de la Biosfera de Mapimi. Actas del Seminario Mapimi, Gomez Palacio (Dgo, México), Instituto de Ecologia and Orstom Eds., pp. 89-110. (octubre 1989).

Bartley, R., Roth, C., Ludwig, J., McJannet, D., Liedloff, A., Corfield, J., Hawdon, A., Abbott, B., 2006. Runoff and erosion from Australia's tropical semiarid rangemands: influence of ground cover for differing space and time scales. Hydrological Processes 20 (16), 3317-3333.

Bergkamp, G., 1998. A hierarchical view of the interactions of runoff and infiltration with vegetation and microtopography in semiarid shrublands. Catena 33, 201-220.

Bonell, M., Gilmour, D.A., 1978. The development of overland flow in a tropical rain-forest catchment. Journal of Hydrology 39 , 365-382.

Braud, I., Vich, A.I.J., Zuluaga, J., Fornero, L., Pedrani, A., 2001. Vegetation influence on runoff and sediment yield in the Andes region: observation and modelling. Journal of Hydrology 254, 124-144.

Cappus, P., 1960. Etude des lois de l'écoulement. Application au calcul et à la prévision des débits. Bassin expérimental d'Alrance. La Houille Blanche, No. A. Grenoble, France, pp. 521-529.

Casenave, A., Valentin, C. 1989. Les états de surface de la zone sahélienne. Influence sur l'infiltration. Col. Didactique. Editions Orstom, Paris, p. 229.

Chevalier, P., 1983. L'indice des précipitations antérieures. Cah. Orstom, sér. Hydrologie XX (3-4), 179-189.

Corradini, C., Morbidelli, R., Melone, F., 1998. On the interaction between infiltration and Hortonian runoff. Journal of Hydrology 204, 52-67.

Cosandey, C., 1994. Formation des crues " cévenoles" dans des bassins élémentaires du Mont Lozère. Revue des Sciences de l'Eau 7, 377-393.

Croke, J., Hairsine, P., Fogarty, P., 1999. Runoff generation and redistribution in logged eucalyptus forests, south eastern Australia. Journal of Hydrology 216, 56-77.

Delhoume, J.-P., 1995. Fonctionnement hydro-pédologique d'une toposéquence de sols en milieu aride (reserve de la Biosphère de Mapimi, Nord-Mexique), PhD memory, Université de Poitiers, France, p. 282.

De Roo, A.D.J., 1993. Modeling surface runoff and soil erosion in catchment using Geographical Information System. Validity and applicability of the ANSWERS model in two catchments in the loess area of Limburg (the Nederlands) and one in Devon (UK). Netherlands Geographical Studies, 157.

Descroix, L., Estrada, E., Nouvelot, J.-F., Thiébaux, J.-P., 1997. Hydrologie du bassin versant de la Ventana. Technical report ORSTOM-Cenid-Raspa, Gomez Palacio, Gdo, México, p. 20.

Descroix, L., Viramontes, D., Vauclin, M., Gonzalez Barrios, J.L., Esteves, M., 2001. Influence of surface features and vegetation on runoff and soil erosion in the western Sierra Madre (Durango, North West of Mexico). Catena, 115-135.

Descroix, L., Nouvelot, J.F., Vauclin, M., 2002a. Evaluation of an antecedent precipitation index to model runoff in the western Sierra Madre (north-west Mexico). Journal of Hydrology 263, 114-130.

Descroix, L., Gonzalez Barrios, J.L., Vandervaere, J.P., Viramontes, D., Bollery, A., 2002b. Variability of hydrodynamic behaviour on soils and hillslopes in a subtropical mountainous environment (Western Sierra Madre, Mexico). Journal of Hydrology $266,1-14$

Descroix, L., Gonzalez Barrios, J.L., Estrada, J., Viramontes, D. (Eds.), 2005a, La Sierra Madre Occidentale, château d'eau menacé. Editions de l'IRD, coll. Latitudes 23, p. 360.

Descroix, L., Viramontes, D., Bouzou Moussa, I., Gonzalez Barrios, J.-L., Besnier, A.-L., Gautier, E., 2005. Land use changes and evolution of fluvial regimes. In: VIlème Assemblée Scientifique de l'AISH, Foz de Iguacu (poster), Avril, 2005.

Descroix, L., Gonzalez Barrios, J.L., Viramontes, D., Poulenard, J., Esteves, M., Bollery, A., 2007. Gully and sheet erosion on subtropical mountainous slopes: their respective role and the scale effect. Catena. doi:10.1016/j.catena.2007.07.003.

Dunne, T., Black, R.D., 1970. An experimental investigation of runoff production in permeable soils. Water Resources Research 6, 179-191.

Esteves, M., Lapetite, J.M., 2003. A multi-scale approach of runof generation in a Sahelian gully catchment: a case study in Niger. Catena 50 (2), 255-271.

Esteves, M., Descroix, L., Mathys, N., Lapetite, J.M., 2005. Field measurement of soil hydraulic properties in a marly gully catchment (Draix, France). Catena 63, 282-298.

Estrada-Avalos, J. 2000. Importance et fonctionnement des petits barrages dans une zone sémi-aride du Nord-Mexique. Science PhD memory, University of Montpellier 2, France, p. 320. 
Freeze, A., 1980. A stochastic - conceptual analysis of rainfallrunoff processes on a hillslope. Water Resources Research 16 (2), 391-408.

Giertz, S., Diekkruger, B., Steup, G., 2006. Physically based modelling of hydrological processes in a tropical headwater catchment (West Africa) _ Porcess representation ans multicriteria validation. Hydrology and Earth System Sciences 10, 829-847.

Gochis, D.J., Brito-Castillo, L., Shuttleworth, J., 2006. Hydroclimatology of the North American Monsoon region in northwest Mexico. Journal of Hydrology 316, 53-70.

Goodrich, D.C., Lane, L.J., Shillito, R.M., Miller, S.N., 1997. Linearity of basin response as a function of scale in a semiarid watershed. Water Resources Research 33 (12), 2951-2965.

Hewlett, J.D., 1961. Soil moisture as a source of base flow from steep mountain watershed. US forest Service, Southeastern Forest Experiment Station, Asheville, North Caroline.

Hewlett, J.D., 1972. Reply on effects of forest clearfelling on the storm hydrograph. Water Resource Research 8 (1), 171-172.

Horton, R.E., 1933. The role of infiltration in the hydrologic cycle. EOS. American Geophysical Union Transactions 14, 44-460.

Horton, R.E., 1940. An approach toward a physical interpretation of infiltration capacity. Science Society of America Proceedings 5, 399-417.

Hughes, D.A., 1994. Soil moisture and runoff simulations using four catchment rainfall-runoff models. Journal of Hydrology 158, 381-404.

Karambiri, H., Ribolzi, O., Delhoume, J.P., Ducloux, J., CoudrainRibstein, A., Casenave, A., 2003. Importance of soil surface characteristics on water erosion in a small grazed Sahelian catchment. Hydrological Processes 17, 1495-1507.

Kohler, M.A., Lindsey, R.K., 1951. Predicting the runoff from storm rainfall. Weather Bureau, US Dept of Commerce, Research Paper No. 34, Washington, $9 \mathrm{p}$

Latron, J., Gallart, F., 2007. Seasonal dynamics of runoff-contributing areas in a small Mediterranean research catchment (Vallcebre, Eastern Pyrenees). Journal of Hydrology 335, 194206.

Mahé, G., Dray, A., Paturel, J.E., Cres, A., Koné, F., Manga, M., Cres, F.N., Djoukam J., Maiga, A., Ouedraogo, M., Conway, D., Servat, E., 2002. Climatic and anthropogenic impacts on the flow regime of the Nakambe river in Burkina. In: Van Lannen, H., Demuth, S. (Eds). FRIEND 2002 Regional Hydrology: Bridging the
Gap Between Research and Practice. Proc. Friend Conf., Cape Town, South Africa, 2002, IAHS, Pub No. 274, pp. 69-76.

Peugeot, C., Cappelaere, B., Vieux, B., Seguis, L., Maia, A., 2003. hydrologoc process simulation of a semi-arid, endoreic catchment in Sahelian West Niger: 1. Model-aided data analysis and screening. Journal of Hydrology 279, 224-243.

Reaney, S.M., Bracken, L.J., Kirkby, M.J., 2006. Use of the connectivity of runoff model (CRUM) to investigate the influence of storm characteristics on runoff generation and connectivity in semi-arid areas. Hydrological Processes 21 (7), 894-906.

Ribolzi, O., Karambiri, H., Bariac, T., Benedetti, M., Caquineaux, S., Descloitres, M., Aventurier, A., 2007. Mechanisms affecting stormflow generation and solute behaviour in a Sahelian headwater catchment. Journal of Hydrology 337, 104-116.

Tricker, A.S., 1981. Spatial and temporal patterns of infiltration. Journal of Hydrology 49, 261-277.

Viramontes, D., 1995. Caracterización de los suelos y la vegetación en la parte alta de la cuenca del Nazas. Publicación OrstomINIFAP, No. 7, Gomez Palacio, DGO, Mexico, 45 p.

Viramontes, D., 2000. Comportement hydrodynamique du milieu dans le Haut Bassin du Nazas (Sierra Madre Occidentale, Mexique). Causes et conséquences de son évolution. PhD thesis, Université Joseph Fourier, Grenoble, p. 440.

Viramontes, D., Descroix, L., 2002. Modifications physiques du milieu et conséquences sur le comportement hydrologique des cours d'eau de la Sierra Madre Occidentale (Mexique). Revue des Sciences de l'Eau 15 (2), 493-513.

Viramontes, D., Descroix, L., 2003. Variability of overland flow in an endoreic basin of northern Mexico: the hydrological consequences of environment degradation. Hydrological Processes 17, 1291-1306.

Wei, W., Chen, L., Fu, B., Huang, Z., Wu, D., Gui, L., 2007. The effect of land uses and rainfall regimes on runoff an erosion in the semi-arid loess hilly area, China. Journal of Hydrology 335, 247-258.

Woolhiser, D.A., Smith, R.E., Giraldez, J.V., 1996. Effects of spatial variability of saturated hydraulic conductivity on Hortonian overland flow. Water Resources Research 32 (3), 671-678.

Ziegler, A.D., Giambelluca, T.W., Plondke, D., Leisz, S., Tran, L.T., Fox, J., Nullet, M.A., Vogler, J.B., Troung, D.M., Vien, T.D., 2007. Hydrological consequences of landscape fragmentation in mountainous northern Vietnam: buffering of Hortonian overland flor. Journal of Hydrology 337, 52-67. 